\title{
Effect of Genotypes and Sugar Type on Callus Formation and Plant Regeneration Derived from Mature Grains of Egyptian Rice
}

\author{
(Oryza sativa L.)Varieties
}

\author{
Sanaa. I. Milad*, M. Abd El-Ghany**, M. M. Saad Alla** and H. M. Abou Zaid** \\ * Biotechnology Laboratory, Crop Science Dept., Fac. of Agric. (El-Shatby), Alexandria Univ., \\ ** Plant Production Dept., Fac. of Agric., Damanhour, Univ., Egypt.
}

\begin{abstract}
The main objective of the present study was to determine the highest regenerable Egyptian rice cultivars and the best source of carbohydrates. Three medium protocols had been used to determine the in vitro culture response of mature dehusked grains in five Egyption rice cultivars. Factorial experiment in CRD design with ten replications was used to analyze the data. The obtained results showed that in vitro traits were highly significantly affected by genotypes and the interaction between medium protocols and genotypes. Whereas, medium protocols had different effects on the in vitro traits. The results also indicated that the shoot formation (\%) and number of shoots per callus traits were highly significantly affected by genotypes, medium protocols and the interaction between medium protocols and genotypes. In conclusion, the cultivars, Sakha 103 and Sakha 104 could be successfully utilized in breeding programs for biotic and abiotic stress tolerance at the cellular level, because of their high frequency of shoot formation on the medium protocol C.
\end{abstract}

Keywords: Rice, Medium protocol, Mature dehusked grains, In vitro culture response, Shoot formation.

\section{Introduction}

Rice (Oryza sativa L.) is the most important food crop and a primary food source for more than $50 \%$ of the world population (Khush and Virk, 2000). It is providing a stable diet for most of the world's population (Xing et al., 2004). It is one of the most versatile and important cereal crops of Poaceae family cultivated for more than 10,000 years (Sasaki, 2005). In Egypt, rice is the most important summer crop, occupying almost $1 / 3$ of the cultivated area 1.88 million faddans (GAIN, 2014). Recently, modern biotechnology overcomes many of the problems associated with conventional breeding. In comparison to conventional breeding, this technique is more precise and allows transfer of traits across species/genera. These techniques also offer creation of variation through somaclonal and gametoclonal variations and consequently facilitate rapid development of new varieties. Development of a high efficient in vitro plant regeneration system is a prerequisite for improvement of the crop by many modern biotechnological means, such as breeding using somaclonal variation and genetic 
transformation (Murat and Arpacioğlum, 2003; Hoque and Mansfield, 2004 and Hussain, et al., 2010).

In rice, many factors affecting in vitro culture response have been intensively investigated due to its important position in staple food production and the impact of breeding. These factors included genotype, culture medium, genotype $\mathrm{x}$ culture medium interaction and the explant source. Genotype, or genetic composition of the plants, has been indicated as a major factor which affects the growth and morphogenesis of tissue cultures (Abe and Futsuhara, 1984; Hartke and Lorz 1989, Oinam and Kothari, 1993 and Raman et al., 1994). Genotypes varied in their capacity for callusing and plant regeneration (Barakat, 1990 and Azria and Bhalla, 2000). Genotypic differences strongly influenced plant regeneration potential (Hoque et al., 2004 and Wang et al., 2007). In vitro growth of plants is largely determined by the composition of the culture medium. Sugar is a very important component in medium and its addition is essential for in vitro growth and development of plants (Pierik, 1987). Sugar in culture medium has been considered the sole carbon source for the growth of cells and tissues (Gauchan, 2012). Genotypes and media composition and their interaction were the major determinants of in vitro response (ElShafei, 2002, Wagiran et al., 2008 and Amer, 2012). In vitro regeneration of rice is possible from different explants such as mature and immature seeds, leaves, shoot bases and root tips (El-Shafei, 2002 and Sharma et al., 2005).

This study describes the assessment of five Egyptian rice cultivars for their capabilities of shoot formation, and subsequently plant regeneration, on three medium protocols using mature dehusked grains explants.

\section{Materials and Methods}

The present work was carried out at the Biotechnology Laboratory, Crop Science Department, Faculty of Agriculture (ElShatby), Alexandria University, Egypt.

\section{Plant materials}

Five Egyptian rice cultivars; namely, Sakha 101, Sakha 103, Sakha 104, Giza 177 (Japonica cultivars) and Giza182 (Indica cultivar) (Table 1), were studied for in vitro manipulation. They were obtained from Rice Research Department, Sakha Agricultural Research Station, Agriculture Research Center (ARC), Ministry of Agriculture and Land Reclamation, Egypt. Mature dehusked grains were surface sterilized by immersing them for $3 \mathrm{~min}$. in $70 \%$ ethanol, followed by immersing in $0.1 \%$ Mercuric chloride for $15 \mathrm{~min}$, then washed with six rinses of sterile distilled water. Mature embryos were aseptically excised and placed in $9 \mathrm{~cm}$ petri dishes containing $20 \mathrm{ml}$ of culture medium, 10 embryos per each dish. Each dish was considered as one replication. Ten replicates were used for each genotype/protocol. Cultures were incubated at $25 \pm 2{ }^{\circ} \mathrm{C}$ under 16 hours illumination (2000 lux, day light fluorescent tubes).

Table 1. Origin, pedigree and type of studied cultivars.

\begin{tabular}{lll}
\hline Variety & Pedigree & $\begin{array}{l}\text { Rice } \\
\text { group }\end{array}$ \\
\hline Sakha 101 & Giza 176/Milyang 79 & Japonica \\
Sakha 103 & Giza 177 / Suweon 349 & Japonica \\
Sakha 104 & GZ 4096-8-1/GZ4100-9 & Japonica \\
Giza 177 & Giza 171/Yomji No.1/PiNo.4 & Japonica \\
Giza 182 & Giza 181 /IR 39422-163-1-2/ & Indica \\
& Giza 181 & \\
\hline
\end{tabular}

\section{Culture media}

Three medium protocols (A, B and C), were used for callus induction, differentiation and root induction. The same basal medium (Murashige and Skoog 1962) and additives were used in each step (1mg/ L 2,4-D and 1.2 
$\mathrm{mg} / \mathrm{L}$ kinetin in callus induction, $0.1 \mathrm{mg} / \mathrm{L}$ ABA and $1.36 \mathrm{~g} / \mathrm{L}$ yeast extract in callus differentiation and free of additives in root induction) for the three protocols but the difference among them was the type of sugar (carbon source) where in protocol A $30 \mathrm{~g}$ of sucrose were added to different media, while in protocol B $30 \mathrm{~g}$ of sorbitol were added to the media. In protocol $\mathrm{C}, 15 \mathrm{~g}$ of each of sucrose and sorbitol were added as carbon source. The $\mathrm{pH}$ of all media was adjusted to pH 5.8 using $1.0 \mathrm{M} \mathrm{HCl}$ or $1.0 \mathrm{M} \mathrm{NaOH}$. The agar was added after adjusting the $\mathrm{pH}$. The media were then sterilized by autoclaving. All equipments and media were steam-sterilized by autoclaving at $121^{\circ} \mathrm{C}$ for $20 \mathrm{~min}$.

\section{In vitro culture response}

After seven weeks of incubation, callus formation response was recorded and the following determinations were recorded within each replicate (petri dish): 1) callus induction (\%) (the percentage of explants which produced callus on the initiation medium), 2) callus weight (g) (the fresh weight of the initiated callus) and 3) embryogenic callus $(\%)$. The calli were transferred to the three differentiation media. After seven weeks, the following determinations were recorded for each petri dish: 4) shoot formation (\%) (the percentage of calli with green shoots which exceeded $1 \mathrm{~cm}$ in length) and 5) number of shoots (the number of green shoots per callus). Regenerated shoots were transferred into MS medium, devoid of growth regulators for further development.

\section{Hardening and acclimatization}

Well rooted plantlets were carefully removed from culture vessels, washed under running tap water to remove agar from the root and were transplanted into small pots, filled with compost. The pots were incubated under moist conditions for adaptation establishment.

\section{Statistical analysis}

Data were statistically analyzed as a factorial experiment with two-factors (genotypes and media), using Completely Randomized Design (CRD), with ten replications. All in vitro traits data, except for the callus weight, were subjected to transformation, prior to statistical analysis (Steel and Torrie, 1980). Number of green shoots /callus was transformed, using square root, and the other traits were transformed, using arcsine transformation. Comparisons among means were made by using the least significant difference test (L.S.D.). The data were analyzed, using SAS program (2002).

\section{Results}

Mature dehusked grains of five rice genotypes were cultured on three culture media (protocols A, B and C) for callus induction. The statistical analysis for the effect of genotypes, medium protocols and their interaction revealed that the in vitro traits of culture response were highly significantly influenced by differences in cultivars, medium protocols and their interaction except the embryogenic callus (\%) which was not significantly affected by medium protocols, however, it was highly significantly influenced by genotypes and the interaction between genotypes and medium protocols (Table 2). 
Table 2. Analysis of variance for callus formation traits as influenced by cultivars, medium protocols and their interaction.

\begin{tabular}{lllll}
\hline \multirow{2}{*}{$\begin{array}{l}\text { Source of } \\
\text { Variance }\end{array}$} & D.F. & $\begin{array}{l}\text { Callus } \\
\text { induction (\%) }\end{array}$ & $\begin{array}{l}\text { Callus weight } \\
\text { (g/explant) }\end{array}$ & $\begin{array}{l}\text { Embryogenic } \\
\text { callus (\%) }\end{array}$ \\
\hline Media (A) & 2 & $880.26^{* *}$ & $5.89^{* *}$ & $239.89^{\text {ns }}$ \\
Cultivars (B) & 4 & $5729.01^{* *}$ & $1.53^{* *}$ & $6203.15^{* *}$ \\
A x B & 8 & $1779.37^{* *}$ & $1.74^{* *}$ & $1337.48^{* *}$ \\
Error & 75 & 171.59 & 0.25 & 179.21 \\
\hline
\end{tabular}

$* *$ : Significant at 0.01 probability level.

ns: Not significant.

Results of the in vitro culture response were elucidated in the following traits:

\section{Callus induction}

The response of callus induction varied, according to medium protocol. Means presented in Table 3 indicated that medium protocol B gave the highest average of callus induction (83\%), across genotypes, with no significant difference from protocol C $(81.6 \%)$, whereas, protocol A was the lowest one $(71.3 \%)$. Results in Table 4 showed that callus induction widely varied among the rice genotypes. The percentage of explants that developed calli ranged from 44.4\% (Giza 182 ) to $96.6 \%$ (Sakha 104). However, Sakha $101(85.5 \%)$ was not significantly different from Sakha $103(86.6 \%)$ and Giza 177 $(80.0 \%)$ cultivars.

Furthermore, data in Table 5 revealed that the rice genotypes differently responded either within the same, or among, the three medium protocols. For example, the cultivar, Sakha 104, gave the highest percentage of callus induction $(98.3 \%)$ when protocol $\mathrm{C}$ and B were used, however, the cultivar Sakha 101 gave the same result when protocol A was used. Conversely, the cultivar Giza 182 recorded the lowest significant callus induction percentage $(0.00 \%)$ when protocol A was used. On the other hand, Giza 182 gave the lowest significant value $(66.6 \%)$ compared with the other values when protocol $\mathrm{B}$ and $\mathrm{C}$ were used with no significant difference from Sakha 101 (78.3\%) when protocol C was used.

\section{Callus weight}

Callus growth and development were influenced by the relationship between the genotypes and the constituents of the medium protocols.

The weight of callus was dependent upon the rice genotypes and the medium protocols employed. Among medium protocols, protocol $\mathrm{C}$ gave the significantly highest callus weight (1.65/explant) and it was significantly superior to protocol A $(0.98$ $\mathrm{g} /$ explant) and protocol B (0.81 g/explant) as shown in Table 3. The cultivar, Sakha 104, produced the highest callus weight (1.51g/explant) across medium.

Table 3. Overall mean values for In vitro culture response traits as influenced by medium protocols.

\begin{tabular}{lllll}
\hline $\begin{array}{l}\text { Medium } \\
\text { Protocol }\end{array}$ & $\begin{array}{l}\text { Callus } \\
\text { induction (\%) }\end{array}$ & $\begin{array}{l}\text { Callus weight } \\
\text { (g/explant) }\end{array}$ & $\begin{array}{l}\text { Shoot } \\
\text { formation (\%) }\end{array}$ & $\begin{array}{l}\text { No. } \\
\text { shoots/callus }\end{array}$ \\
\hline $\mathrm{A}$ & $71.3 \mathrm{~b}$ & $0.98 \mathrm{~b}$ & $0.06 \mathrm{~b}$ & $0.13 \mathrm{~b}$ \\
$\mathrm{~B}$ & $83.0 \mathrm{a}$ & $0.81 \mathrm{~b}$ & $0.20 \mathrm{~b}$ & $0.36 \mathrm{~b}$ \\
$\mathrm{C}$ & $81.6 \mathrm{a}$ & $1.65 \mathrm{a}$ & $0.66 \mathrm{a}$ & $1.33 \mathrm{a}$ \\
\hline
\end{tabular}

Means follow by the same letter (s) are not significantly different at 0.05 level. 
Table 4. Overall mean values for In vitro culture response traits as influenced by cultivars.

\begin{tabular}{cccccc}
\hline Cultivar & $\begin{array}{c}\text { Callus } \\
\text { induction (\%) }\end{array}$ & $\begin{array}{c}\text { Callus weight } \\
\text { (g/explant) }\end{array}$ & $\begin{array}{c}\text { Embryogenic } \\
\text { callus (\%) }\end{array}$ & $\begin{array}{c}\text { Shoot } \\
\text { formation (\%) }\end{array}$ & $\begin{array}{c}\text { No. } \\
\text { shoots/callus }\end{array}$ \\
\hline Sakha 101 & $85.5 \mathrm{~b}$ & $1.2 \mathrm{ab}$ & $79.4 \mathrm{ab}$ & $0.33 \mathrm{ab}$ & $0.66 \mathrm{ab}$ \\
\hline Sakha 103 & $86.6 \mathrm{~b}$ & $1.25 \mathrm{ab}$ & $82.7 \mathrm{ab}$ & $0.38 \mathrm{ab}$ & $0.72 \mathrm{ab}$ \\
\hline Sakha 104 & $96.6 \mathrm{a}$ & $1.51 \mathrm{a}$ & $88.3 \mathrm{a}$ & $0.61 \mathrm{a}$ & $1.27 \mathrm{a}$ \\
\hline Giza 177 & $80.0 \mathrm{~b}$ & $1.06 \mathrm{~b}$ & $76.1 \mathrm{~b}$ & $0.11 \mathrm{~b}$ & $0.11 \mathrm{~b}$ \\
\hline Giza 182 & $44.4 \mathrm{c}$ & $0.71 \mathrm{c}$ & $30.0 \mathrm{c}$ & $0.11 \mathrm{~b}$ & $0.27 \mathrm{~b}$ \\
\hline
\end{tabular}

Means follow by the same letter (s) are not significantly different at 0.05 level.

Table 5. Mean values for In vitro culture response traits as influenced by the interaction between medium protocols and cultivars.

\begin{tabular}{|c|c|c|c|c|c|c|c|c|c|}
\hline \multirow[t]{2}{*}{ Cultivar } & \multicolumn{3}{|c|}{$\begin{array}{l}\text { Callus induction } \\
\text { Medium protocol }\end{array}$} & \multicolumn{3}{|c|}{$\begin{array}{l}\text { Callus weight } \\
\text { Medium protocol }\end{array}$} & \multicolumn{3}{|c|}{$\begin{array}{l}\text { Embryogenic callus } \\
\text { Medium protocol }\end{array}$} \\
\hline & A & B & C & A & B & C & A & B & C \\
\hline Sakha 101 & $98.3 \mathrm{a}$ & 80.0 bcde & $78.3 \mathrm{cde}$ & $1.85 \mathrm{~b}$ & $0.64 \mathrm{e}$ & $1.1 \mathrm{cde}$ & $95.0 \mathrm{a}$ & $70.0 \mathrm{~cd}$ & $73.3 \mathrm{~cd}$ \\
\hline Sakha 103 & $85.0 \mathrm{bcd}$ & 80.0 bcde & $95.0 \mathrm{ab}$ & $1.05 \mathrm{cde}$ & $0.86 \mathrm{de}$ & $1.85 \mathrm{~b}$ & $81.6 \mathrm{abc}$ & $76.6 \mathrm{bcd}$ & $90.0 \mathrm{ab}$ \\
\hline Sakha 104 & $93.3 \mathrm{abc}$ & $98.3 \mathrm{a}$ & $98.3 \mathrm{a}$ & $1.23 \mathrm{~cd}$ & $0.74 \mathrm{de}$ & $2.54 \mathrm{a}$ & $90.0 \mathrm{ab}$ & $91.6 \mathrm{ab}$ & $83.3 \mathrm{abc}$ \\
\hline Giza 177 & $\begin{array}{l}80.0 \\
\text { bcde }\end{array}$ & $90.0 \mathrm{abc}$ & $70.0 \mathrm{de}$ & $0.76 \mathrm{de}$ & $1.16 \mathrm{cde}$ & $1.27 \mathrm{~cd}$ & $80.0 \mathrm{abc}$ & $86.6 \mathrm{ab}$ & $61.6 \mathrm{de}$ \\
\hline Giza 182 & $0.00 \mathrm{f}$ & $66.6 \mathrm{e}$ & $66.6 \mathrm{e}$ & $0.00 \mathrm{f}$ & $0.65 \mathrm{e}$ & $1.48 \mathrm{bc}$ & $0.00 \mathrm{f}$ & $46.6 \mathrm{e}$ & $43.3 \mathrm{e}$ \\
\hline
\end{tabular}

Table 5. Continued.

\begin{tabular}{ccccccc}
\hline \multirow{2}{*}{ Cultivar } & \multicolumn{3}{c}{$\begin{array}{c}\text { Shoot formation } \\
\text { Medium protocol }\end{array}$} & \multicolumn{3}{c}{$\begin{array}{c}\text { No. of shoot/callus } \\
\text { Medium protocol }\end{array}$} \\
\cline { 2 - 7 } & A & B & C & A & B & C \\
\hline Sakha 101 & $0.16 \mathrm{bc}$ & $0.33 \mathrm{bc}$ & $0.50 \mathrm{~b}$ & $0.5 \mathrm{~cd}$ & $0.33 \mathrm{~cd}$ & $1.16 \mathrm{bc}$ \\
Sakha 103 & $0.00 \mathrm{c}$ & $0.00 \mathrm{c}$ & $1.16 \mathrm{a}$ & $0.00 \mathrm{~d}$ & $0.00 \mathrm{~d}$ & $2.16 \mathrm{ab}$ \\
Sakha 104 & $0.00 \mathrm{c}$ & $0.50 \mathrm{~b}$ & $1.33 \mathrm{a}$ & $0.00 \mathrm{~d}$ & $1.00 \mathrm{bc}$ & $2.83 \mathrm{a}$ \\
Giza 177 & $0.16 \mathrm{bc}$ & $0.00 \mathrm{c}$ & $0.16 \mathrm{bc}$ & $0.16 \mathrm{~cd}$ & $0.00 \mathrm{~d}$ & $0.16 \mathrm{~cd}$ \\
Giza 182 & $0.00 \mathrm{c}$ & $0.16 \mathrm{bc}$ & $0.16 \mathrm{bc}$ & $0.00 \mathrm{~d}$ & $0.5 \mathrm{~cd}$ & $0.33 \mathrm{~cd}$ \\
\hline
\end{tabular}

protocols, however, it was not significantly different from Sakha 103 (1.25g/explant) and Sakha 101(1.2g/explant), while cultivar "Giza182" gave the lowest callus weight $(0.71 \mathrm{~g} /$ explant) and was significantly different from Giza 177 (1.06 g/explant) as indicated in Table 4.

Moreover, Table 5 illustrated that genotypes and medium protocols highly significantly interacted with each other. The five rice cultivars were different in their response according to the medium protocol. The cultivar "Sakha 104" had the highest significant callus weight $(2.54 \mathrm{~g} / \mathrm{explant})$ when medium protocol $\mathrm{C}$ was used. On the other hand, "Giza 182" gave the lowest significant callus weight $(0.00 \%)$ when medium protocol A was used. Otherwise, the remaining genotypes and medium protocols gave variable values.

\section{Embryogenic callus}

Embryogenic callus of rice is easy to recognize by its characteristics as pale yellow glistening, smooth surface and compact appearance. In early stages of formation, the whole callus might be smooth, but, eventually, it becomes a mass of green nodules (meristemoids) which often turned over into leaf-like structures. 
Differences in the ability of callus to form a mass of green nodules (embryogenic callus), were observed among different rice genotypes in the present investigation (Table 4). The highest percentage of embryogenic callus was observed in "Sakha 101" across medium protocols $(88.3 \%)$, which was not significantly different from Sakha 101 (79.4\%) and Sakha $103(82.7 \%)$, whereas, Giza 182 gave the significantly lowest percentage of embryogenic callus (30\%), which was significantly different from Giza 177 (76.1\%).

Moreover, data in Table 5 illustrated that genotypes and medium protocols highly significantly interacted with each other. The five rice cultivars were different in their response, according to the medium protocol. The cultivar "Sakha 101" had the highest significant percentage of embryogenic callus (95\%) when medium protocol A was used, which was not significantly different from Sakha $103(81.6 \%)$ when protocol $\mathrm{A}$ and $(90.0 \%)$ when protocol C were used, from Sakha 104 across all protocols and from Giza $177(80.0 \%)$ when protocol $\mathrm{A}$ and $(86.6 \%)$ when protocol B were used. However, "Giza 182 " gave the lowest significant percentage of embryogenic callus $(0.00 \%)$ when protocol A was used. Otherwise, the remaining genotypes and medium protocols gave variable values.

\section{Morphogenetic Response}

The calli derived from mature dehusked grains, which were induced on the three induction media, were transferred on three different differentiation media. After six weeks data were recorded. Some calli did not differentiate and others formed shoots. The following determinations were recorded.

\subsection{Shoot formation (\%)}

The medium protocol $\mathrm{C}$ gave the highest percentage of shoot formation across cultivars $(0.66 \%)$, whereas, medium protocol A gave the lowest significant percentage of shoot formation $(0.06 \%)$ as shown in Table 3.

Results in Table 4 showed that shoot formation widely varied among rice genotypes. The cultivar "Sakha 104" produced the highest mean of shoot formation $(0.61 \%)$ which was not significantly different from "Sakha 103" (0.38\%), whereas, " Giza 182 " gave the significantly lowest percentage of shoot formation $(0.11 \%)$.

Furthermore, data in Table 5 revealed that the rice cultivars differently responded either within the same or among the three medium protocols. The cultivar, Sakha 104, gave the highest percentage of callus formation $(1.33 \%)$ when protocol $\mathrm{C}$ was used, which was not significantly different from cultivar Sakha 103 $(1.16 \%)$ when the same medium protocol was used, however, the cultivars Giza 182, Sakha 103 and Sakha 104 recorded the lowest callus formation percentage $(0.00 \%)$ when protocol A was used. The cultivar Sakha 103 and Giza 177 gave the same result $(0.00 \%)$ when protocol B was used.

\subsection{Number of shoots/callus}

According to the results showed in Table 3, the medium protocol, $\mathrm{C}$ gave the highest mean of number of shoots/callus across cultivars (1.33), whereas medium protocol A gave the lowest significant mean of number of shoots/callus (0.13), which was not significantly different from protocol B (0.36).

It is clear from Table 4 that the number of shoots/callus widely varied among rice cultivars. The cultivar "Sakha104" produced the highest mean number of shoots/callus (1.27), which was not significantly different from Sakha103 (0.72) and Sakha101 (0.66), whereas, "Giza 177" gave the lowest number of shoots/callus (0.11), which was not significantly different from "Giza 182" (0.27). 
It was evident from Table 5 that medium protocols and rice cultivars significantly interacted with each other. This means that the three cultivars differently responded, according to the medium protocol. Sakha 104 gave the highest significant number of shoots (2.83) when protocol C was used, however, Sakha 103, Sakha 104 and Giza 182 gave the lowest number of shoots $(0.00)$ when protocol A was used. Sakha 103 and Giza 177 gave the same number of shoots $(0.00)$ when protocol B was used.

Roots were readily formed on plantlets, using MS- based agar medium without phytohormones. Plants were established under greenhouse conditions and whole plants, at flowering stage, were obtained.

\section{Discussion}

Mature dehusked grains were used as the explant in this study because several previous studies reported that mature seeds have been successfully used in rice in vitro culture $(\mathrm{Wu}$ and Li, 1971; Jones, 1985 and Oard and Rutger, 1988). Barakat (1990) reported that mature embryos of rice cultivars were a convenient starting material for in vitro culture, since it could be stored and was more readily available at any time of the year. Mature dehusked rice seeds were used as an explant because calli, initiated from scutellum of mature seeds of all rice cultivars, had a high embryogenic potential (Ge et al., 2006; Khaleda and Al-Forkan, 2006 and Hussain et al., 2010). Embryogenic calli, obtained from mature seed explant, have high regeneration capacity (Khalequzzaman et al., 2005). MS basal medium was used in this study because many of the previous results revealed that it was the most commonly used (Rashid et al., 1996; Toki 1997 and Hussain et al., 2010).

The results of this study suggested that, before utilizing tissue culture technique as a tool for crop improvement, it was necessary to determine the factors influencing callus formation, its quality and quantity during induction and maintenance and, subsequently, shoot regeneration from callus. The same suggestion was recorded by Mohamed et al. (2000), El-Shafei (2002) and El-Basyoni (2006).

The growth and multiplication of shoots in vitro are affected by many factors, one of which is the concentration and type of exogenous carbon source added to the medium. The carbon source serves as energy and osmotic agents to support the growth of plant tissues (Lipavska and Konradova, 2004). In addition, growth and root initiation are highly energy requiring processes that can occur at the expense of available metabolic substrates, which are mainly carbohydrates (Calamar and De Klerk, 2002).Among the sugars, sucrose is used as a principal carbon source for in vitro plant culture, probably because it is the most common carbohydrate in the phloem sap of many plants.

The results of this study indicated that the use of $15 \mathrm{~g} / \mathrm{L}$ sucrose $+15 \mathrm{~g} / \mathrm{L}$ sorbitol enhanced callus induction, proliferation and regeneration potential compared with sucrose or sorbitol alone. These results were similar to the findings of Al-khayri et al. (1996), who studied the effect of sucrose and sorbitol on callus induction and regeneration, reported that the sucrose/sorbitol combination improved regeneration of some rice cultivars. In addition, Shahsavari (2011) and Al-Kaaby et al. (2013) showed that the addition of $20 \mathrm{~g} / \mathrm{L}$ sorbitol in the culture media increased regeneration response. However, $30 \mathrm{~g} / \mathrm{L}$ sorbitol decreased the response in both callus induction and regeneration frequencies.

Genotype is another important factor affecting the in vitro growth. The result of this study showed that the efficiency of callus induction, callus growth rate and regeneration 
were affected by genotype, where the response of Japonica cultivars to the in vitro culture was better than the Indica cultivars. The in vitro response have been reported previously to be, in part, genotype dependent and the highly significant differences among cultivars, in the in vitro culture response, were in agreement with previous studies (Barakat and AbdelLatif, 1995; Özgen et al., 1998, Milad et al., 2001; Hassan et al., 2003; Nasircilar et al., 2006; Raziuddin et al., 2010 and Abdallah et al., 2012) who pointed out that tissue culture abilities of Japonica rice were better than those of Indica rice. These results were also supported by Hoque et al. (2004), who found that genotypic differences strongly influenced plant regeneration potential.

The present investigation revealed that genotypes $\mathrm{X}$ medium protocols (carbon source) interaction largely affected callus induction and plant regeneration. Such results are in agreement with previous findings of Barakat and Abdel-Latif (1995), Milad et al. (2001), Hassan et al. (2003), Yasmin et al. (2009) and Abdallah et al. (2012).

The results reported by El-Shafei (2002) revealed that there was a cultivar $\mathrm{x}$ medium protocol interaction for morphogenetic response. The probable reasons of differences in morphogenetic response, in vitro, might be attributed to: (a) Genetic differences among the used cultivars, (b) Differences in growth stimulators or (c) Differences in the growth conditions.

\section{Conclusion}

The results of the present experiment indicated that the cultivars Sakha 103 and Sakha 104 could be successfully utilized in breeding programs for biotic and abiotic stress tolerance at the cellular level, because of their high frequency of shoot formation on the medium protocol C (15 g/ L of each of sucrose and sorbitol). This study of morphogenesis provide useful information for subsequent investigations to improve rice genotypes using biotechnological tools. However, further research is needed to know the impact of carbon sources on development of shoots and the physiological changes during growth of rice.

\section{Reference}

Abdallah, H. A. L., Said, A. E. and Khalafalla, M. M. M. (2012) Establishment of an efficient callus induction and plant regeneration system in some wheat (Triticum aestivum L.) cultivars grown in Sudan, Afric. J. Biotech, 11 (16): 3793-3799.

Abe, T. and Futsuhara, Y. (1984) Varietal difference of plant regeneration from root callus tissues in rice, Jpn. $J$. Breed, 34: 147-155.

Al-Kaaby, H. K., Abdul-Qadir, L. H. and Kareem, M. E. (2013) Effect of sorbitol on callus induction and somatic embryos regeneration in two local wheat (Triticum aestivum L.) cultivars, Journal of Basrah Researches Sciences, 39 ISSN 1817-2695.

Al-Khayri, J. M., Shamblin, C. E., McNew, R. W. and Anderson, E. J. (1996) Callus induction and plant regeneration of U.S. rice genotypes as affected by medium constituents, In Vitro Cell. Dev. Biol., 32: $227-232$

Amer, S. M. (2012) In Vitro selection and molecular markers for improving drought tolerance in some Egyptian rice cultivars, M.Sc., Faculty of Agriculture, Alexandria University, Egypt.

Azria, D. and Bhalla, P. L. (2000) Plant regeneration from mature embryo derived callus of Australian rice (Oryza sativa L.) varieties, Aust. J. Agric. Res. 51 (2): 305-312.

Barakat, M. N. (1990) Genotype and media effects on callus formation and regeneration in rice (Oryza sativa L.), Alex. J. Agric. Res. 35 (2): 39-51.

Barakat, M. N. and Abdel-Latif, T. H. (1995) Somatic embryogenesis in callus from mature and immature embryo culture of wheat, Alex. J. Agric. Res., 40:7795.

Calamar, A. and De Klerk, G. J. (2002) Effect of sucrose on adventitious root regeneration in apple, Plant Cell Tiss. Org. Cult., 70, 207.

El-Basyoni, S. I. (2006) In vitro selection for salinity tolerance in wheat, M.Sc. Faculty of Agriculture, Alexandria University, Egypt.

El-Shafei, A. A. (2002) Towards in vitro selection studies for rice drought tolerance in rice, M.Sc. Faculty of Agriculture, Alexandria University, Egypt. 
GAIN (Global Agricultural Information Network) (2014) This Report Contains Assessments of Commodity and Trade Issues Made by USDA Staff and Not Necessarily Statements of Official U.S. Government Policy. USDA Foreign Agricultural Service. USA.

Gauchan, D. P. (2012) Effect of different sugars on shoot regenerartion of Maize (Zea mays L.), Kathmandu University Journal of Science, Engineering and Technology, 8 (I): 119-124.

Ge, X. J., Chu, H. Z., Lin, Y. J. and Wang, S. P. (2006) A tissue culture system for different germplasms of Indica rice, Plant-Cell Report, 25 (5): 392-402.

Hartke, S. and Lorz, H. (1989) Somatic embryogenesis and plant regeneration from various indica rice (Oryza sativa L.) genotypes, J. Genet. Breed, 43: 205-214.

Hassan, Q. M., Shah, S. H. and Ali, S. (2003) Effect of genotype and medium on wheat callus induction, Sarhad J. Agric., 19 (1): 69-71.

Hoque, E. H. and Mansfield, J. W. (2004) Effect of genotype and explant age on callus induction and subsequent plant regeneration from root-derived callus of Indica rice genotypes, $\mathrm{Pl}$. Cell Tiss. Org. Cult., 78: 217223.

Hoque, E. M., Ali, M. S. and Karim, N. H. (2004) Embryogenic callus induction and regeneration of elite Bangladeshi Indica rice cultivars, Plant Tissue Cult. \& Biotech, 17 (1): 65-70.

Hussain, Z., Khan, M. H., Bano, R., Rashid, H. and Chaudhry, Z. (2010) Protocol optimization for efficient callus induction and regeneration in three Pakistani rice cultivars, Pak. J. Bot., 42: 879-887.

Jones, T. J. (1985) Somatic embryogensis and plant regeneration from four varieties of rice (Oryza sativa L.), Amer. J. Botany, 72 (6), 804.

Khaleda, L. and Al-Forkan, M. (2006) Genotypic variability in callus induction and plant regeneration through somatic embryogenesis of five deepwater rice (Oryza sativa L.) cultivars of Bangladesh, African Journal of Biotechnology, 5 (16): 1435-1440.

Khalequzzaman, M., Haq, N., Hoque, M. E. and Aditya, T. L. (2005) Regeneration efficiency and genotypic effect of fifteen Indica type, Bangladeshi rice (Oryza sativa L.) Landraces, Plant Tissue Cult., 15 (1): 3342.

Khush, G. S. and Virk, P. S. (2000) Rice Breeding: Achievement and future strategies, Crop Improv., 27: $115-144$

Lipavska, H. and Konradova, H. (2004) Somatic embryogenesis in conifers: The role of carbohydrate metabolism, In Vitro Cell Dev. Biol. Plant, 40: 2330.
Milad, S. I., Motawei, M. I., Barakat, M. N., Moustafa, M. A. and El-Daoudi, Y. H. (2001) Genotype and media effects on somatic embryogenesis and shoot formation in some Egyptian wheat cultivars (Triticum spp.), Alex. J. Agric. Res., 46: 37-46.

Mohamed, M. A. H., Harris, P. J. C. and Henderson, J. (2000) In vitro selection and characterization of a drought tolerant clone of Tagetesminuta, Plant Sci., 159: $213-222$.

Murashige, T. and Skoog, F. (1962) A revised medium for rapid growth and bioassays with tobacco tissue cultures, Physiol. Plant., 15: 473-497.

Murat, Ö. and Arpacioğlum, N. (2003) Cytoplasmic effects on the tissue culture response of winter durum wheat (Triticum durum Dest.) callus, Korean J. Genet., 25 (1): $9-13$

Nasircilar, A., Turgut, G. K. and Fiskin, K. (2006) Callus induction and plant regeneration from mature embryos of different wheat genotypes, Pak. J. Bot., 38 (2): 637-645.

Oard, J. H. and Rutger, J. N. (1988) Callus induction and plant regeneration in elite U.S. rice lines, Crop Sci., 28: $565-567$

Oinam, G. S. and Kothari, S. L. (1993) Genotypic differences in emberyogenic callus formation and plant regeneration in Indica rice, Intern. Rice Res. Notes, 18 (3): 9-10.

Özgen, M., Turet, M., Altinok, S. and Sancak, C. (1998) Efficient callus induction and plant regeneration from mature embryo culture of winter wheat (Triticum aestivum L.) genotypes, Pl. Cell Rept., 18 (3-4): 331-335.

Pierik, R. L. M. (1987) In vitro culture of higher plants, Martinus Nijhoff, Dordrecht, 24.

Raman, R., Chahal, G. S. and Dhaiwal, H. S. (1994) Screening of genotypes for callus induction and plant regeneration in rice, Crop Improvem., 21 (1-2): 30-36.

Rashid, H., Yokoi, S. and Hinata, K. (1996) Transgenic plant production mediated by Agrobacterium in Indica rice, Plant Cell Rep., 15: 727-730.

Raziuddin, J.B., Swati, Z.A., Shafi, M., Ullah, F. and Akmal, M. (2010) Effect of cultivars and culture medium on callus formation and plant regeneration from mature embryos of wheat (Triticum aestivum L.), Pak. J. Bot., 42 (1): 639-652.

SAS. (2002) SAS/STAT. Guide for personal computers. Version 8.1 edn. SAS end. SAS institute, Cary. N. C, USA.

Sasaki, T. (2005) The maped base sequence of the rice genome, Nature, 436: 793-800. 
Shahsavari, E. (2011) Contribution of sorbitol on rgeneration of embryogenic calli in upland rice, INT, Journal of Agriculture and Biology, 838-840.

Sharma, V. K., Hänsch, R., Mendel, R. R. and Schulze, J. (2005) Mature embryo axis-based high frequency somatic embryogenesis and plant regeneration from multiple cultivars of barley (Hordeum vulgare L.), J. Exp. Bot., 56: 1913-1922.

Steel, R. G. D. and Torrie, J. H. (1980) Principles and Procedures of Statistics: A Biometrical Approach, McGraw-Hill Book Company, NY. USA. 633 p.17.

Toki, S. (1997) Rapid and efficient Agrobacterium transformation in rice, Plant Mol. Biol. Reporter, 15 (1): $16-21$.

Wagiran, A., Ismail, I., Radziah, C., Zain, C. M. and Abdullah, R. (2008) Improvement of plant regeneration from embryogenic suspension cell culture of japonica rice, Journal of Biological Sciences, 8: 570-576.
Wang, H., Zhang, H., Gao, F., Li, J. and Li, Z. (2007) Comparison of gene expression between upland and lowland rice cultivars under water stress, using cDNA microarray, Theor. Appl. Genet., 115: 11091126.

Wu, L. and Li, H. W. (1971) Induction of callus tissues initiation from different somatic organs of rice by various concentrations of 2,4-dichlorophenoxyacetic acid, Cytologia, 36: 411-416.

Xing, H., Tan, L., An, L., Zhao, Z., Wang, S. and Zhang, C. (2004) Evidence for the involvement of nitric oxide and reactive oxygen species in osmotic stress tolerance of wheat seedlings: Inverse correlation between leaf abscisic acid accumulation and leaf water loss, Plant Growth Reg., 42: 61-68.

Yasmin, S., Khan, I. A., Khatri, A., Seema, N., Nizamani, G. S. and Arain, M. A. (2009) In vitro plant regeneration in bread wheat (Triticum aestivum L.), Pak. J. Bot., 41 (6): 2869-2876. 
تأثير التركيب الوراثي ونوع السكر على تكوين الكالس وإنتاج النباتات من الحبوب الناضجة لأصناف الأرز المصري (Oryza sativa L.)

سناء إبراهيم محمد ميلاد*، ومحمد عبدالغنى رمضان**، محمد محمد سعد الله** وهناء محمد مهذى أبو زيد** "معمل الثقنية الحيوية، قسم الدحاصيل، كلية الزراعة (الثاطبى)، جامعة الإسكندرية،

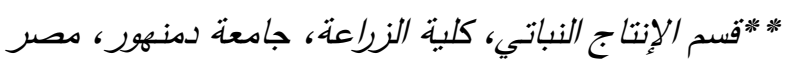

الدستخلص. كان الهذف الرئيس لهذه الدراسة تحديد أعلى أصناف الأرز الصصري فى قدرته على إعطاء

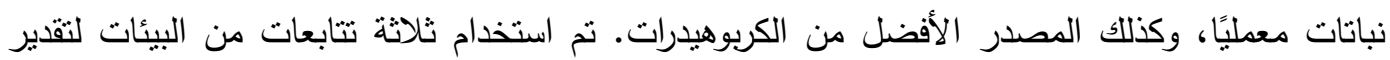
الاستجابة للزراعة معمليًا فى الحبوب الناضجة المقشرة لخمسة أصناف من الأرز الدصري. تم استخدام

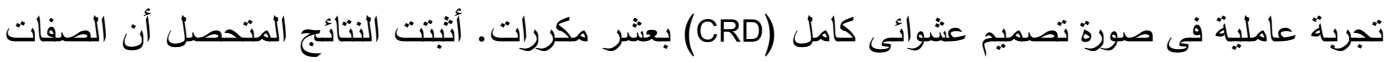
المعطلية تأثرت نأثيرًا عالي المعنوية بالتركيب الوراثي والتفاعل بين التتابع البيئي والتركيب الوراثي. ولكني

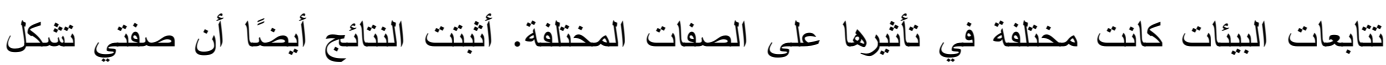

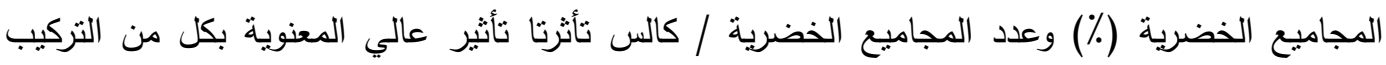

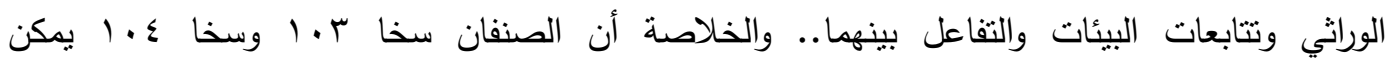

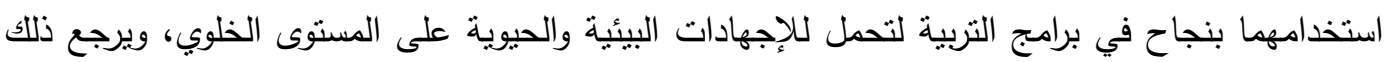
إلى القدرة العالية على إنتاج نباتات على تنابع البيئات C. C.

الكلمات الدالة: الأرز، تتابع البيئات، الحبوب الناضجة المقثرة، الاستجابة للزراعة المعطلية، تتكل المجاميع الخضرية. 
